\title{
"It's your family that kills you": Responsibility, Evidence, and Misfortune in the Making of Ndyuka History
}

\author{
STUART EARLE STRANGE
}

Yale-NUS College

\section{IN TR O DUCTION}

Da Antony lay dying in a hammock in the corner of the room. Emaciated and frail, a man who had been so recently vigorous now only stared silently at the whiteness of the far wall as members of his large extended family filed in and out of his home in a squatter settlement on the outskirts of Paramaribo, Suriname. On the porch, out of his earshot, I could overhear quiet speculation about the evidence his symptoms disclosed for why he was now at the limits of life. Was it a kin-person's envious witchcraft, or an unavoidable consequence of Da Antony's own actions or those of his lineage? What caused his affliction and plainly approaching death? And how would his dying define his lineage's persistence into the future?

For the urban Ndyuka Maroons I lived with between 2007 and 2013descendants of seventeenth- and eighteenth-century escaped enslaved Africans who founded independent societies in Suriname's rainforest-events of affliction like Da Antony's mortal illness were history, direct eruptions of "past relations" "materially located within" present events (Collingwood 1946; Keane 2003: 410). This article describes the conditions and contradictions that define the emergence of socially authoritative historical events from contemporary Ndyuka attempts to assign responsibility for affliction and death. For many

Acknowledgements: I wish to gratefully acknowledge the invaluable support of the National Science Foundation (Award \#1123530), the Social Science Research Council, and the Wenner-Gren Foundation in funding this research. I would also like to thank John Willems, Paul C. Johnson, Geoffrey F. Hughes, Ismail Alatas, Joshua Reno, H.U.E Thoden van Velzen, Joshua Shapero, David Akin, Rogerio Brites Pires, and Gabriele Koch for their incisive comments and contributions. 
urban Ndyuka, I argue, misfortune and suffering are potentially paradigmatic historical events because they act as primary evidence for the reality of the past and present social relations held to cause them. Accordingly, critical dimensions of Ndyuka historical experience arise from the tense interplay between the material symptoms of misfortunes and the techniques that Ndyuka use to negotiate personal and collective responsibility.

I approach events of affliction as vital to the creation of Ndyuka sociality and the negotiation of authority. The forms these events take can prompt the appearance of past relations in the material infirmities of quotidian Ndyuka existence. Present-day Ndyuka responses to affliction events disclose critical dimensions of their historical awareness, and how this awareness is integrated into the new urban conditions under which most Surinamese Maroons now live.

Rather than portray any final event as history, I will track the features of affliction that convinced Ndyuka that I know to recognize themselves as either responsible for past ancestral actions and ongoing ecological relationships, or as guiltless victims of living kinsmen's malice. To clarify the complexities of Ndyuka history-making, this paper describes why the symptoms of one exemplary event of affliction failed to metastasize into a fact about a family's collective past. Doing so demonstrates how a distinct Ndyuka experience of history is created from the ways in which urban Ndyuka simultaneously seek to recognize and contest the responsibility made evident by the physical characteristics of their sufferings.

EVENTS OF AFFLICTION AS MATERIALS OF HISTORY AND R E S P ON S I B I L I T Y

As the nervous murmurs that accompanied Da Antony's passing indicated, discourses of responsibility exercise critical influence over what Ndyuka people recognize as events of collective history (Schieffelin 1985; Sahlins 1985; Munn 1986; Keane 2003; Wirtz 2016). Not unlike many Ndyuka, academic historians demand a distinctive formulation of responsibility. Inherited directly from Voltaire's attempt to wrest events away from divine providence, academic historiography has routinized European Enlightenment metaphysics of contingent human freedom (Löwith 1949). As Fasolt argues, "In the very act of demanding that sources must be interpreted according to the context of their time and place, history asserts that sources reflect the thought, action, or creation of some individual agent who can be held responsible for what he thought, did, or made at some definite point in past time and space, because he was at liberty to think, do, or make something else" (2005: 6, my emphasis). In making historical interpretation dependent on traces of the accountability of liberal European subjects for "individual" choices, much contemporary academic history continues to naturalize a particular theory of responsibility that often complicates collective accountability for historical action (Johnson 
2014). Because of the metaphysical specificity of this view of history, no matter how responsibility is disciplined, it lingers as a potential, potent lesson that different understandings of past and future continue to compete for recognition in equally influential ways (Latour 1992; Fasolt 2004; Chakrabarty 2009; Palmié 2014).

Empirically, understanding the co-constitution of history and responsibility requires comparing the distinctive techniques that social groups use to translate the qualities of events into compelling analyses of social life. This necessitates apprehending how the material qualities of events like the symptoms of an illness or the timing of an accident "afford" different authoritative accounts of responsibility through time and among different actors (Keane 2015). Whether approached as fixed laws or unique moments of radical change, for events to be historical they must become "action under description" (Anscombe 1957; Hacking 1995). That is, the social intelligibility of an event derives from the ability of descriptions to supply answers about why it occurred. Such descriptions never arise in isolation, but are dependent on "deeply felt cultural assumptions concerning the ways events in the world are constructed and how actions are meaningfully related to one another" (Schieffelin 1985: 48). In this respect, all practices of history are bound up in "systems of accountability" (Douglas 1980: 58) that determine how responsibility is inferred from events. If this is so, one way to "provincialize" (Chakrabarty 2000) standard academic historiography within an inclusive "anthropology of history" is to compare the past relationships created by diverse practices of defining and distributing responsibility over space and through time (Palmié and Stewart 2016: 208).

The anthropology of history outlined above requires detailed appreciation of what counts when and for whom as evidence of the past and its connection to the present (Lambek 1998; 2003; Parmentier 1985; Wirtz 2016). Whether as elusive memory or the veritable co-presence of the dead, the past depends on the materials of the present to address the living and hold them accountable (Cashell 2013; Lambek 2003; Wirtz 2016). By postulating different "logicalcausal" (Munn 1986; Keane 2003) relations between the materiality of events and their social implications, alternative constructions of responsibility destabilize theories of historical causation too easily assumed by EuroAmerican history and social sciences (Laidlaw 2014). ${ }^{1}$ For Ndyuka people, such "logical-causal" differences are clearest when history is witnessed in

\footnotetext{
1 As helpfully noted by a CSSH reviewer, history need not be limited to causal sequences or their discovery. That said, for people like the Ndyuka, causation does occupy a pivotal place in their conception of history because it is fundamentally a description of differences between consubstantial social groups like lineages that derive their corporate identity from shared accountability to an inextinguishable ancestral past.
} 
events of affliction, by which I mean the numerous accidents, illnesses, and disappointments that puncture the daily course of all human lives.

Despite the complexity of Evans-Pritchard's (1937) analysis of Azande witchcraft, debates over the rationality, social function, or metaphysical reality of explanations have taken precedence over understanding how the qualities of "unfortunate events" intersect with cultural paradigms of responsibility (Horton 1997; Douglas 2004 [1970]; Holbraad 2012). Even in Turner's (1968) foundational work on "cults of affliction," the characteristics of events of affliction are treated as tertiary to the social drama of the ritual processes employed to heal suffering. Recent innovations in the witchcraft literature like West (2007), Geschiere (2013) Favret Saada (2015), and especially Bubandt (2014), have focused on the affective and epistemological practices that engender the social salience of witchcraft discourses. Though these authors' approaches actively describe the evidences used to discern events of witchcraft, in each case evidence remains secondary to a favored theory of meaning that isolates witchcraft's power in language, therapy, kinship, and doubt.

When the nature of the eventfulness of events has become an explicit anthropological or historical topic, it is often in terms of the contingent independence of events from "culture" or "society" as quanta of a "natural" history that exceeds human meanings (Sahlins 1985; Latour 1992; Keane 2003; Palmié and Stewart 2016). To remedy this cleaving of matter and sense, theorists have focused on the event as process, “.... a singularity of forces in which critical dimensions of socio-cultural existence reveal new potentials of the ongoing formation of socio-cultural realities" (Kapferer 2015: 2). ${ }^{2}$ Events do not merely happen; they must be compellingly described as evidence of their wider existential ramifications. Even when assessed as "meaningless" accidents, once recognized, events become structures of accountability capable of clarifying where blame falls and how people should react to it (Akin 2003).

As structures of accountability, events both compose time and are composed by it. Whether developed by corporate managers or shamans, the "world making" potential of variable temporalities depends on how they "fit" evidence and event together in compelling descriptions of the sequencing of agents, actions, and consequences (Overing 1990; McGovern 2012). In this

\footnotetext{
2 As Kristina Wirtz argues (2016), rather than approach the eventfulness of "structures of the conjuncture" as exceptional cases of encounter, scholars might also attend to the diversity of potential social relations embedded in the materials that mediate the implications of everyday interaction, from names, quotes, and arguments to places, symptoms, or accidents. Events are assemblages of simultaneity, the material qualities of which are decisively determinant of their sociocultural consequences. This notion of an unfolding node of sociocultural "formation" originates from Sahlins' influential warning that an event is "not simply a happening in the world," but rather "a relation between a certain happening and a given symbolic system" (1985: 153). Events are "structures of the conjuncture" (1981) that emerge from the unfolding, punctuated interdependence of meaning and materiality in and across social and historical contexts.
} 
way, history - the eventfulness of events as "moments of immanence and the affirmation and realization of potential" (Kapferer 2015: 2) - is imbricated with what Laidlaw, drawing on Douglas (1980) and Gluckman (1972), calls a "mechanism of accountability for responsibility" (2014: 201). Whether events are attributed to God, witches, or personal merit, as diverse "mechanisms" for affixing responsibility such descriptions "...create their own kinds of interconnectedness" (ibid.: 201) that differently distribute attribution of causes across a social context and between moments of time. ${ }^{3}$ Accordingly, whether events like illnesses are ascribed to bad hygiene or divine wrath conditions how people reflect on their own actions and experience historical accountability (Keane 2003; 2015).

For the Ndyuka I know, the question made famous by Evans-Pritchard (1937) - why do bad things happen to certain people at particular moments - demanded that the precise qualities of events of affliction be interrogated as signs of the social relations perceived to cause them (see Favret Saada 1981; 2015; Bubandt 2014). Every serious misfortune might implore accountability, making the accurate assessment of responsibility a dominant concern of Ndyuka collective history. Since Ndyuka etiologies do not sharply distinguish physical ailments from social suffering such as poverty, even relatively trivial misfortunes like lost property can act as potential clues that a victim and their kin group are entangled in opaque, transgenerational relations of responsibility. Such corporate responsibility is possible because the central medium of Ndyuka history, the matrilineage (bée), is also the primary vector of the hereditary avenging spirits $($ kunu) and the resentful witchcraft that afflict grief and death on lineage members across time. As the common Ndyuka saying has it, "Your mother's family is what kills you."

The heritability of history is a distinctive facet of the unique temporalities of Maroon life detailed by Price $(1983 ; 2007)$ and Moomou (2016). For many Ndyuka, the most consequential temporal distinction is between the present of the living (libisamaten) and the ancestral past, especially the period of maroonage (fesiten) when Ndyuka emerged as a people. Though concealed by death, in both the blood of kinship and spirits and ghosts who reside in the lives and bodies of the living, historical actors and events persist into the present. By definition immortal, whether autochthonous to Suriname or brought from Africa, these spirits (gadu/wenti) act as enduring witnesses to the historical relations from whom the living derive their existences and identities. In this regard, Ndyuka history is as much an epistemological as a temporal problem. The

${ }^{3}$ Because signs "are symptoms, direct or mystified, of the true force of things" (Sahlins 1981: 7), their interpretability depends on the material forms that make a storm, an illness, or a ritual evidence of relations of responsibility. In this way all events, however trivial, "address" (Bakhtin 1981; Lempert 2011) an audience insofar as they are seen as evidence for socially salient categories of responsibility - the ability to respond to being addressed (Trnka and Trundle 2014). 
condition of the living is to be determined by, but excluded from, definite knowledge of past and future. All that mortals know is that they are consubstantially inculpated by descent in the obligations and offenses of their kin. Though this clamps Ndyuka in a vice of collective destiny, the equivocal qualities of any event of misfortune also authorize spirit mediums and oracles able to see the past to provide multiple, and frequently competing, accounts of historical responsibility.

For many Ndyuka, the idiosyncratic synchronicity of a specific person being harmed in a particular way makes the characteristics of events of affliction prima facie evidence for specific enduring relations and conditions of relatedness. In this sense, unfortunate events explain witchcraft and other intentionally afflicted sufferings as much as they are explained by it. ${ }^{4}$ Though avenging spirits and matrilineality are a governing influence on how contemporary Ndyuka apprehend connections of accountability and history, they are still among a miscellany of often overlapping or conflicting causal explanations that include personal incompetence (dondon), trespassed taboos (kina, teefu), and witchcraft (wisi). The importance of accurately determining accountability from among this jumble of agents, relations, intentions, and temporalities forces Ndyuka to carefully consider how responsibility is materialized by the configuration of when, to whom, and in what way a particular illness or accident happens.

While Ndyuka are happy to dismiss certain occurrences as "accidents" (ongoku) without wider implication, the social significance of an event of affliction proceeds from the ways in which it makes definite relations of responsibility apparent. The likelihood that everyone within an Ndyuka kin group is incriminated by an event of affliction means that, whether or not a headache or a sudden fall is ultimately deemed inconsequential, its features still need to be interrogated as a potentially socially significant message for the kin group as whole.

Just as with medical symptoms or accident investigations, the members of Ndyuka kin groups can find it a challenge to demonstrate firm responsibility for an event of affliction, and interpretations are often contested - the same material congruence that provides one group of interpreters' incontestable evidence of witchcraft or an avenging spirit may provoke vehement doubts among other social factions. Ndyuka must wrestle attributions of responsibility for such events from a variety of evidences and argue for their interpretive authority across differently implicated constituencies of kin. This complexity can render the simplest happenings into events of potentially explosive significance, binding people together or driving them apart, and transforming how kin understand their relations to one another to change their collective

\footnotetext{
${ }^{4}$ I thank Geoffrey Hughes for this formulation.
} 
history. Indeed, as Thoden van Velzen and van Wetering (2004; 2007) have shown, the revolutionary political power of major Ndyuka spirit mediums, from Labi Agumasaka in the late nineteenth century to Gáangá in the first decade of the twenty-first, resulted from their temporary ability to dramatically restrict collectively relevant explanations of misfortune. ${ }^{5}$

\section{THE CONTEXT OF DA ANTONY'S ILLNESS}

To show how afflictions act as paradigmatic events of Ndyuka history, the rest of this article presents a detailed study of one emblematic case. I will track changing explanations of responsibility for the affliction that killed Da Antony. Unfolding over many months, his illness and final death show how different collective histories emerge from the interplay between the qualities of an event of affliction and the kin-based politics of attributing responsibility among contemporary urban Ndyuka.

Da Antony was an "up-river" (opose) man of the Dyu clan (lo) from the Ndyuka homeland along the Tapanahoni River in eastern central Suriname. The Ndyuka are one of Suriname's six recognized Maroon communities (Parris 2011; Thoden van Velzen and van Wetering 2004) who now comprise the second-largest and fastest growing segment of Suriname's multi-ethnic population. Ndyuka ancestors escaped coastal plantations into the vast interior and waged a seventy-year guerrilla war against the Dutch authorities until their freedom was recognized in return for peace in 1760 (Thoden van Velzen and Hoogbergen 2011). During the period of armed struggle, the Ndyuka and other Surinamese Maroons adopted indigenous techniques of shifting cassava agriculture, foraging, and hunting. Since emancipation, they have pursued life in their remote villages in Suriname's rainforests, supplementing what they could grow or forage with coastal goods bought by men laboring in timber and transport. Though the majority of Ndyuka now live semipermanently in and around Suriname's capital of Paramaribo or in neighboring French Guiana, Ndyuka have maintained this subsistence base into the present.

That said, rapid urbanization resulting from the search for better education, employment, and healthcare has forced key modifications in Ndyuka life. More Ndyuka, particularly women, have become fulltime wageworkers in Suriname's coastal capitalist economy, living away from the interior villages and their kin-based structures of authority. While this has brought sweeping changes to Ndyuka life, the rituals that enact and enforce kin-focused practices

\footnotetext{
${ }^{5}$ Gáangá, a medium then in his mid-twenties, led the most recent major anti-witchcraft movement during eight months in 2006. He ascribed all misfortune to demons (bakuu) purchased by wealthy Ndyuka, often traditional leaders, and led violent witch-hunts to force confessions in which people were severely beaten, forced to drink noxious potions, and had their property destroyed. The movement ended after Gáangá was imprisoned during a visit to Paramaribo. The movement revealed the breakdown of traditional authority and the limits on autonomous social action in Ndyuka territory.
} 
remain vital, even if they increasingly lack the persuasive power they have in the interior.

When I got to know him, Da Antony estimated he was in his early seventies. He had lived in Suriname's capital city of Paramaribo and its outlying squatter settlements since the 1970s when he arrived to work for the Surinamese government as a petty official. He was also one of his matrilineage's basiya, a political title with significant, if hardly uncontested, prestige combining the roles of town crier, ritual aide, and legal enforcer. ${ }^{6}$ Before he became ill, Da Antony routinely returned to his village to coordinate major rituals and communal politics and communicate the results to kin in the capital. Even in the city where the position is often truncated to making decisions about funerals, traditional titles like basiya invite respect and provide a valued government salary and a smart official uniform.

By the time I met him in January 2012, Da Antony had been suffering for close to two years from a persistent hoarseness later diagnosed as throat cancer. Though he sought allopathic care when the sickness began, his doctor either failed to identify the cancer or withheld the diagnosis. ${ }^{7}$ I had lived in Da Antony's natal village during earlier research and so knew many of his extended kin. Introduced by his son-in-law, the retired and highly knowledgeable Da Antony had been happy to answer my questions and I was soon visiting him every day. Being a white foreigner living in a nearly exclusively Maroon settlement, I was soon asked by Da Antony's family to help intervene with Creole and Indo-Surinamese hospital doctors who were habitually prejudiced against Maroons. By the time we became friends the cancer had unmistakably advanced, and although Da Antony eventually enrolled in radiation therapy he died in May 2013.

Da Antony's illness grew as a cause of collective concern the longer it persisted. Initially, though his close relatives told me that he was sick and actively seeking remedies, there was no sense that his condition might be fatal. The cures he sought included ritual interventions by Ndyuka oracular healers (obiyaman, bonuman). Da Antony never said exactly how many healers he had seen, but I know that he conferred with at least three during the four months I helped with his daily care. Because treatments are evaluated in terms of their effectiveness, as each failed to produce results Da Antony's affliction gathered significance for his extended family: in his suffering they began descry a common guilt that might lead to not only his death but also their own.

\footnotetext{
${ }^{6}$ He was appointed a basiya during the tenure of Gaanman Gazon Matodja (1968-2011).

7 Though I have no evidence of wrongdoing, at least one of Da Antony's doctors, whom he had just met, told me that people "like him" (meaning Maroons) were incapable of understanding allopathic medicine, and therefore such diagnoses were wasted on them because they would not follow the appropriate course of treatment. Such prejudice is unfortunately common in Suriname.
} 
THE EVENT OF AFFLICTION IN NDYUKA HISTORY

To better understand the pivotal social emphasis that Ndyuka grant events of affliction like Da Antony's illness, we must look to how Ndyuka kinship makes collective history felt. For most Ndyuka, through avenging spirits and witchcraft, kin-relations are conceived as a structure of destiny and suspicion, an enduring frame of distributed responsibility that ensures that personal actions always have collective consequences. Ndyuka trace their ancestry through both parents, but with a strong matrilineal bias. Organized into thirteen matrilineal clans further divided into lineages that dominate social life from birth to death, Ndyuka place great emphasis on how their matrilineal relations transmit property, political belonging, and, crucially, collective responsibility (Thoden van Velzen and van Wetering 2004; Parris 2011). As people share identity and substance with their matrilineage, so they too must bear responsibility for their fellow lineage members' actions. Past acts of violence and disrespect committed by matrilineal relatives result in events of spirit vengeance randomly disseminated among lineage members. Although solidarity through communal rites of propitiation temporarily mollifies these spirits, Ndyuka are convinced that their wrath persists until the guilty lineage dies out (Thoden van Velzen 1966; Price 1973; Green 1977).

Events of affliction caused by avenging spirits and witches make kinship, especially matrilineages (bée) and matrilineal segments (wan mama piikin), the most immediate and demanding transmitters of Ndyuka historical consciousness. Lineage history coheres from narratives of collective ancestral escape from slavery, and the migration and settlement of the nascent clans and lineages in their current homeland along the Tapanahoni River. Though Richard Price (1983; 2007), Kenneth Bilby (1990), H.U.E Thoden van Velzen and Wim Hoogbergen (2011), and Jean Moomou (2013) have documented powerful historical memories of the ancestors who founded Maroon societies in the eighteenth century, such information is still highly guarded. While the broad outlines of these histories are common knowledge, elders work to conceal the details of clan and lineage origins. In doing so, they regulate access to stillpotent ancestral power and deny their enemies sorcerous contact with a lineage's avenging spirits. In this way, the very power of the past removes its main agents from most peoples' immediate concerns and imbues knowledge of it with peril.

As I have argued elsewhere (Strange 2016), the Ndyuka I know approached serious misfortunes as signs of a repertoire of relations that have different moral consequences for the afflicted and their family. Whether mediated by kinship or the workplace, Ndyuka try to decipher the relations divulged by any particular affliction. In doing so, they attempt to represent themselves as passive victims rather than as personally responsible for their afflictions, in contrast with greedy, individualistic witches who bear full responsibility for 
their destructive urges. Because it is imperative to avoid charges of witchcraft, Ndyuka depend on various forms of divination to prove that they are docile aggregates of historically mediated relations with ancestors, living kin, and spirits devoid of decisive agency.

This translates to a distinct conception of history demarcated by a restless ritual focus on misfortune. For Ndyuka, any event of affliction can be a historical relation that "flashes up at a moment of danger" (Benjamin 1967: 247). One of the most striking things about living with urban Ndyuka is that annual communal events carry only secondary importance for them. Rather than smooth repetitions of calendric time, Ndyuka social life constantly copes with an ever-gathering tragedy, the signs of which are potentially found in each moment of misfortune. Though Ndyuka enthusiastically celebrate Surinamese national holidays like abolition day (Keti Koti), and have recently adopted personal birthday celebrations, such cyclical events make less of a social demand than do crises, especially funerals, accidents, and illness. Funerals, in particular, dominate Ndyuka social life; these require elaborate preparation and intensive collaboration among large extended families to pay for expensive weeks-long mourning rituals. Because of this, Ndyuka society can appear to be in a constant state of emergency, something expressed by the common Ndyuka expression that humans are "incapable" (á poi) of holding back incessant death.

The concern with attributing responsibility for misfortune in Ndyuka mortuary rites quickly immerses us in the textures of Ndyuka history. As Thoden van Velzen and W. van Watering (2004; 2007; 2011), Parris (2011), and Vernon (1992) have shown, Ndyuka history has been shaped by a powerful need to assess responsibility for every individual death. This imperative was enshrined in the Gaan Gadu anti-witchcraft cult established by the Ndyuka oracular healer Labi Agumasaka that systematically diagnosed all Ndyuka deaths for seventy years starting in the 1890s. Through interlocking methods of divination, upon death every corpse was submitted to an oracular autopsy to assess why they died. In the majority of cases it was found that the person was either a victim of witchcraft or had been punished by the "Great God" for being a witch. Once identified as a witch, the deceased's property was seized and sent to the main Gaan Gadu oracle at the Ndyuka capital of Diitabiki where it was either abandoned in the forest, redistributed to the oracle's priests, or purified and partially returned to the dead persons' family.

Such precautions around property are necessary because all kin are similarly accountable for the resources and relations they share. Every Ndyuka person is held to live through relations of kinship sustained by many generations of gardening, hunting, and remunerative labor. When a person relies on resources created by another, they are ethically enmeshed in the moral conditions that produced those life-sustaining goods-especially if they were 
obtained through witchcraft - and enduringly imprinted with others' past actions.

Gaan Gadu's cult regulated Ndyuka life and death until the 1970s when the prophet Akalali dismantled it during a pan-Ndyuka anti-witchcraft purge by claiming that the god's priests had become witches and subverted the oracle's diagnoses to fulfill their own greed. Despite the widespread success of Akalali's reforms, they left a yawning hole in Ndyuka attempts to produce incontrovertible knowledge about the causes of misfortune and death. Though "down-river" (bilose) Ndyuka clans eventually reinstated corpse divination, up-river Tapanahoni Ndyuka like Da Antony and his family maintain Da Akalali's prohibition. The absence of a method for diagnosing death with pan-Ndyuka authority has resulted in pronounced uncertainty for many Ndyuka. This has created an opening for decentralized innovations in traditional ritual and an insurgent Christianity, both of which have expanded ever faster in the wake of the prophet Gáangá's failed attempt to repeat Akalali's success by violently imposing a single, inflexible witchcraft diagnosis throughout Ndyuka territory in 2006. Now no one has the power to guarantee that witches will be punished for their crimes, a situation that gives greater strength to the avenging spirits who continue to add an expanding roster of witchcraft victims to their ranks.

The absence of a single pan-Ndyuka oracle has made the need to ascertain responsibility for ceaseless death and misfortune more acute, even as it has eroded the power of specific mediums and oracles. At present, each death is still subject to whispered speculations, but divinatory inquests lack uniformly binding validity. This forces contemporary Ndyuka to remain alert to signs of approaching disaster and do their best to bring together relevant kin under common narratives of historical responsibility to protect against further communal suffering. At the same time, urban migration and conversion to Christianity makes it increasingly unmanageable to assemble people for lineage-wide rituals or firmly attribute responsibility for a person's death. ${ }^{8}$ Consequently, while the collective stakes of relatives' misfortunes drive people to read the symptoms of afflictions for evidence of responsibility, urban Ndyuka life further diminishes the ability of any of these interpretations to attain lasting general assent.

\section{BA TYAIUWII'S DIAGNOSIS}

Because unrecognized relations with spirits from the past or contemporary witches threaten to kill off entire lineages, Da Antony's illness needed to be made to communicate the ethical implications of the social relations it

\footnotetext{
8 Though I cannot delve into conversion here, my research with Christian Ndyuka makes clear that much of Christianity's appeal derives from churches' promises to free people from hereditary suffering and the social responsibility enforced by consubstantial kinship.
} 
manifested. If Da Antony was suffering from the personified spirit of ancestral guilt (literally "sin," zondu) or intra-family hostility, he was differently implicated than if he was the passive victim of a witch's "evil heart" (ogii ati). Was he the guiltless victim of another's malice, or the active principal, however unwitting, of pernicious intra-lineage antagonism?

To answer this question in a context of weakened divinatory consensus, many urban Ndyuka pay careful attention to the insistent and contagious characteristics of their afflictions. Whatever the final etiology, Da Antony's sickness had to be understood through the ways its symptoms acted as evidence both for why he suffered and for who else was threatened by the relation or relations it revealed. In Da Antony's case, his illness had reduced him to a choked rasp, something continually commented on by his children, who fondly reminisced about how beautiful their father's voice had been when he sang, told folk tales, or called people together for council meetings. For Da Antony and his co-implicated kin, the strangled quality of his voice offered evidence of connections to either past or future obligations of responsibility and proposed boundaries for the affliction's probable transmissibility to his kin. This made the diagnosis of his misfortune into a moment of history-making; out of the underdetermined material qualities of Da Antony's affliction emerged sometimesdissonant ascriptions of intention, relatedness, and accountability, any of which might convert his sickness into an event of lineage-wide significance. Whether derived from the ancestral past or the present day, any diagnosis could threaten the entire family and future generations with historical responsibility.

During the initial months of my friendship with Da Antony, his sister's son, the spirit medium (lukuman) Ba Tyaiuwii, repeatedly called on him at home. In these visits Ba Tyaiuwii attempted to cajole Da Antony into visiting his healing shrine (obiya kampu) an hour's journey on the road south from Paramaribo. Ba Tyaiuwii maintained that Da Antony needed to come to resolve an issue with one of his daughters by a former girlfriend. At the same time, Ba Tyaiuwii presented himself as fully conversant with the causes of $\mathrm{Da}$ Antony's affliction and repeatedly insinuated that he was the only person who could provide the correct treatment.

After a few of Ba Tyaiuwii's visits, and telephone calls from Da Antony's youngest (and then pregnant) daughter Sonya, Da Antony finally asked me to accompany him to the shrine. Though Ba Tyaiuwii saw this as belated recognition by Da Antony of his healing authority, the two kinsmen quickly started to argue over the correct interpretation of Da Antony's illness.

Ba Tyaiuwii maintained that Da Antony's sickness was "fiofio"- - a punitive spirit caused by unresolved anger between people, especially kin. Against this, Da Antony insisted that only witchcraft was to blame. Both diagnoses stemmed from the complex ways in which Ndyuka analyze the power of speech events and assess responsibility for what is said and to whom. 
For them, sociality is an innate moral state of mutuality (libi makandii) preserved by interpersonal "respect" (lesipeki). Disrespecting others causes anger (ati boon), which, in the event of death, births avenging spirits. Responsible mutuality, however, is a precarious achievement of "talk" (taki) - the political politesse that, often through ancestral proverbs (odoo), permits consensus among otherwise willful people.

The importance of respect makes Ndyuka intensely aware of the power of language to transform reality: as the common Ndyuka saying goes, "a mofu taki tyai ogii" (talk brings evil). Equally rooted in ancestral intervention and living human selfishness, words are attributed independent force and agency that, when combined with strong sentiments of anger, result in independent spirits of revenge with the power to physically harm others. In the case of fiofio, the failure of people to recognize mutuality-especially when compelled by shared genealogies - in dialogue and to avoid confrontation spontaneously transforms verbalized antagonism into a heritable malignant being. Moments of conflict thus take on different temporal implications from the fleeting concord of mutual respect. This endows Ndyuka temporality with a pronounced affective quality. Strong emotions of anger warp time in the same manner that they distort relations, ensuring the transmission of destructive emotions into the non-contiguous future. Accordingly, fiofio enforce the recognition that all living Ndyuka people are subordinate, interdependent embodiments of their lineages' histories.

Witchcraft (wisi), on the other hand, depends on the murky relation of words to intentions. Though uttering curses is one kind of witchcraft, what is more frightening for Ndyuka is that witches (wisiman) ordinarily conceal their true intentions to harm; sooner or later every Ndyuka person I know took me aside to warn me to "trust no one!" (á fiitow sama). The slightest social irregularities may retrospectively become signs of witchcraft, making misgivings among even the closest kinsfolk an existential imperative in ways that frequently contradict the supposedly inviolate moral force of the matriline.

For Da Antony and his immediate family, the fact that his loss of voice undermined his position as a basiya - a title defined by the holder's ability to call people together and provide a feedback structure to formal political oratory-strongly evinced witchcraft. Da Antony did not know exactly who was to blame among his kinsmen for his illness, but he knew that the loss of his voice verified their malefic intent. This implies that the intentions that define responsibility for Ndyuka are an emergent quality of the means used to find them within an event. The "opacity" (Robbins 2008; Bubandt 2014) of others' intentions forced my Ndyuka interlocutors to rely on multiple strands of corroboration to substantiate the causes of events of affliction. Because Ndyuka simultaneously describe others' intentions as the reason afflictions are socially legible, and hold that these intentions are normally inaccessible to accurate human interpretation, a premium is placed on connecting 
the apparent qualities of events to extra-human occult knowledge. In this way, resemblances between symptoms and social relations - the synchrony of the when, where, how, and who of an event of affliction with the conditions of previous social uncertainties - conjoin with the edicts of dreams, possessed mediums, and oracles.

Ba Tyaiuwii's verdict of fiofio grew from a controversy then roiling Da Antony's wider family. As it happened, Sonya, the youngest daughter, had become sexually involved with her classificatory patrilateral brother, an incestuous relation held to be both sinful and transgressive (misi futu) against the lineage, its ancestors, and hereditary spirits. Ignoring repeated warnings to desist, Sonya became pregnant and gave birth to a son who died soon after delivery. Only shortly before, the arm of Sonya's sister became paralyzed. With the aid of his spirit guides, Ba Tyaiuwii described this confluence of unfortunate happenings as interrelated elements of a single event of collective misfortune.

Seeing events of affliction as signs of social relations acts to expand or contract the "time-space" (Munn 1986) of the events from which Ndyuka compose their collective history. Ba Tyaiuwii's diagnosis and the alternative account of Da Antony and his children illustrate some of the ways that afflictions act or become historically important events for present-day Ndyuka. For Ba Tyaiuwii, even before his spirit weighed in, the most noteworthy element of Da Antony's affliction was its temporal congruence with a number of other misfortunate incidents involving his immediate family. This conjuncture indicated a relationship between the afflictions themselves, assembling otherwise distinct features into a single event to reveal a specific matrix of relevant kin-relations.

In Ba Tyaiuwii's account, Da Antony's loss of voice points to his disproportionate responsibility for the failures of respect that brought together these specific afflictions into one collective event of misfortune. If the affliction was a sign of menacing discord (buuya) among his descendants and patrilateral kin, then Da Antony was at least partially responsible for his own misfortune. As a father, a senior maternal uncle (gáan tiyu), and a basiya, he was obliged to maintain comity between family members. Instead, he had argued with his stubborn daughter in a way that only intensified her dangerous intransigence. According to Ba Tyaiuwii, while Sonya's sexual irresponsibility caused considerable acrimony within the family, the stifling of Da Antony's voice communicated his responsibility for further enflaming the situation by holding Sonya to inadequate account. In Ba Tyaiuwii's telling, Da Antony's affliction was punishment for the breakdown of mutual respect among lineage members and a failure to preserve moral fidelity to lineage history.

Supported by his children, Da Antony rejected this interpretation. They insisted that his symptoms bore all the marks of witchcraft. If Da Antony accepted Ba Tyaiuwii's explanation and came to receive protracted treatment 
at his shrine, he would have had to express contrition under the therapeutic authority of his nephew, effectively ceding him ritual preeminence within their matrilineal sub-segment. Construing Ba Tyaiuwii's diagnosis as an attempt to gain influence, Da Antony overruled it, clearly resenting it as a claim to superior knowledge and ethical conduct.

Da Antony and his children by his primary wife stringently denied that he had failed in his duties as family head. He would not accept any description that undermined his moral continence or surrender his legitimacy to junior claimants within the family. Whatever else was said, Da Antony knew himself to be thoroughly moral. Against Ba Tyaiuwii, he perceived his loss of voice as a sign that he was a blameless recipient of another's malice. He saw the discord within his family as the result of envious witchcraft from his native village because his maternal relatives resented him for his ethical stature, the basiya title conferred on him by a coalition of living and dead members of his lineage, and a gift of walky-talkies that he gave to a fellow titleholder.

Because Da Antony strongly surmised that the loss of his voice was evidence of others' vindictive witchcraft, he construed his daughters' misfortunes as a separate event from his own affliction. His sickness, he pointed out, had begun before Sonya's incestuous relationship. For this assessment to hold, Da Antony had to rebuff any association between his newborn grandson's sudden, tragic death and his own ailment. Though he acknowledged the dangers of Sonya's incest and the conflict it bred, he argued that her afflictions were the consequence of possession by bakuu demons - commercially transacted familiars and presently the major tools of Ndyuka witchcraft (Vernon 1980; Thoden van Velzen and van Wetering 2004) - transmitted not from him but through her and her sister's matriline.

Accordingly, Da Antony's dislike of his nephew's usurping maneuvers was compounded by his frustration over Sonya and her sister having moved into Ba Tyaiuwii's shrine for extended treatment. Though predominantly matrilineal as far as property, political position, and collective chastisement are concerned, Sonya's situation revealed the complicated ways Ndyuka negotiate kinship between patrilineal (dada bée) and matrilineal (mma bée) commitments. While the matrilineage transmits the physical substance of relatedness through shared blood (buulu), fathers provide the labor and resources that nurture their children into maturity. ${ }^{9}$ As is regularly the case, this relation

\footnotetext{
9 These issues make the question of kinship difficult. Ndyuka are formally matrilineal, but because of the danger mediated by matrilineal kinship, they sometimes go to great lengths to reconfigure their lineal identities. Patrilineal relatives may "buy" (bai) children, making them de jure members of the paternal family to shield them from the matrilineally mediated vengeance of a spirit or a witch. This is precisely what happened in the case of Da Antony's children, who, due to the repeated predations caused by a matrilineal great uncle, renounced their matrilineal affiliation and now identified wholly with their agnatic family. While this did not prohibit their relations with their matrilineal relatives, it created a new structure of identification that prompted them to identify
} 
predisposed Sonya to look to her patrilineal cousin Ba Tyaiuwii for protection from witchcraft. In this context, however, competing descriptions of Sonya's affliction as either a matrilineally mediated demonic attack or the result of Sonya's own stubborn pursuit of an incestuous relation resulted in real ambivalence on the part of her kin, making collective ritual solutions difficult. ${ }^{10}$

This struggle was dramatized by Ba Tyaiuwii's sudden possession (bali, literally "yelling") by his Kumanti — an archetypal war spirit of masculine valor and competition inherited from the earliest Ndyuka warriors-during my visit to the shrine with Da Antony. Immediately after revealing his diagnosis, Ba Tyaiuwii leapt to his feet and began to animatedly address Da Antony in the esoteric Kumanti language that Ndyuka men hurl at one another in agonistic displays of ritual power. Clearly uncomfortable, Da Antony reacted with nervous laughter; pleading weakness due to illness and age, he began to slowly walk towards our car to leave. Ba Tyaiuwii followed him, but Da Antony remained unflappable even as his nephew needled him with his performance of occult prowess. Though he declined to explain, I took Da Antony's refusal to engage as a rebuttal of his nephew's obstreperousness, a firm declaration that he remained in control of the situation as Ba Tyaiuwii's elder and uncle. Walking away, waving his hand dismissively behind him at the hopping, shouting Ba Tyaiuwii, Da Antony made clear to all present that he would look elsewhere for confirmation of the relations responsible for his illness and their impact on his lineage's future.

\section{DA IWAN'S ETIOLOGY}

Da Antony's frustrations over competing explanations of his illness illustrate Laidlaw's contention that the "interpretation of not only why but actually what happened is inseparable from" judgments about the character of an action (2014: 185). Effectively assigning responsibility depends on fixing how and if an action is intended as a sign of enmity, friendship, or chance, and therefore whether or not it communicates a relationship of some isolable kind. Since for many Ndyuka this quotidian human condition of needing to evaluate the meaning of events extends beyond visible causal relations to invisible bonds of guilt and kinship mediated by numerous spirit agents, Ndyuka descriptions of responsibility quickly escalate in complexity. The partial anchoring of these relations in physical symptoms simultaneously intensifies

\footnotetext{
more closely with their father's kin. The traditionally segmentary structure of Ndyuka kinship makes the consequences of these re-identifications substantial. Feuds and conflicts based on lineage and clan membership are then subject to the complex cross-cutting dynamics of those who perceive their matrilineality as an existential threat.

10 This difficulty was compounded by Ma Umankoni, Da Antony's primary wife, who openly resented his dalliances with other women and was vocally cool about their children, whom Da Antony tended to discuss only when she was out of hearing.
} 
the existential requisite of accounting for responsibility, even as it makes accountability more difficult to discern within the time and materials of any specific event.

Becoming still sicker, two months after his disagreement with Ba Tyaiuwii, and a few other allopathic and traditional treatments later, Da Antony was diagnosed with cancer. In hopeful desperation, his daughter Sa Annette invited yet another mediumistic healer home to identify the affliction's true cause. In his late middle age, Da Iwan was a member of a different clan who shared distant patrilineal kin with Da Antony. He was the medium of a "mixed" (mokisi) Native American (Ingi) and forest (Ampuku) spirit, but had not completed all the necessary rituals for his spirit to achieve full public legitimacy.

I caught Da Iwan's consultation just as it began. Sitting on the verandah with Da Antony, his wife Ma Umankoni, and Sa Annette, Da Iwan began to speak in the distinctive chirps of his spirit's language. Within minutes, the spirit revealed that $\mathrm{Da}$ Antony was suffering from the avenging spirit of a Royal python (papa sneki) that he killed accidentally while burning a new garden many years ago. Da Iwan connected the strangled, whispered quality of Da Antony's voice with the hiss of the snake, and described Da Antony's illness as like an out of balance scale, on which he seesawed between feelings of imminent death and complete recovery.

The family responded enthusiastically to Da Iwan's diagnosis. Ma Umankoni quickly corroborated it, saying that she had dreamed about the snake, as had a woman who had visited Da Antony in the hospital. Da Iwan told them that Da Antony's treatment would have to be performed at a forest camp; it would also be very expensive since, in addition to the ritual, they would have to pay for all of its many ingredients and bring the larger part of Da Antony's extended family. Once everyone agreed to the expedition, Da Iwan poured a libation of clear rum. He asked for the intervention of all the major beings of the Ndyuka cosmos in hierarchical order then sprayed the remaining liquid on Da Antony's neck.

Da Iwan's therapy, like all "traditional" (kulturu) healings I observed, targeted the relations responsible for misfortune within the sufferer's body, which is treated as a composite of various spirit and ancestral identities from the sufferer's genealogy. Mediums and other healers wash people with medicinal formulas (obiya) to remove or appease these invisible imbroglios and seal off a person and their kin-group from further vulnerability to the offending relations.

Because distinctive diagnoses denote different intensities and radii of shared suffering, Da Iwan's verdict marked a change in Da Antony's family's strategy for dealing with his illness. Prior to the cancer diagnosis, Da Antony and his family had been unhappy but calm about his condition. The illness was serious, but had persisted for two years without any effects other than the loss of his voice, and so they had not devoted their full energies to a treatment. They had deemed it sufficient for him to try sporadic remedies 
and wait and assess the results. Once admitted into the medical system with cancer, however, his family urged him to undergo radiation therapy. The therapy, though, soon precipitated a notable physical decline, and he became lethargic and lost weight. He no longer possessed the energy to dismiss etiologies he distrusted. In consequence, his family, especially his wife and her two older daughters, took over his treatment almost completely.

Da Iwan's diagnosis now charged Da Antony with a form of responsibility somewhere in between that suggested by Ba Tyaiuwii's fiofio and Da Antony's preferred diagnosis of witchcraft. Da Antony was responsible, as Ba Tyaiuwii maintained, but not knowingly so as a result of rash anger, as fiofio implied. Though all of the family involved with Da Iwan's finding feared the serpent spirit's wrath, Da Antony's guilt was accidental, a sad but frequently inevitable repercussion of having fulfilled his duty as an Ndyuka man to clear gardens for his wives.

Ndyuka history is, if not just, intrinsically moral. While time is reckoned as irreversibly flowing from past to future, suffering bears with it consequences that stitch contemporary lives to past acts of violence. Ndyuka often explained to me that guilt is inheritable because it is materially transmissible. All actions that sustain life, from farming to earning a wage, have the potential to disrespect an array of seen and unseen others. Such affronts disrupt the entangled mutuality of dignity that binds humans with one another and to spirits, animals, plants, and the landscape. When a person benefits, however unwittingly, from such ethical failures, their dependents are equally liable, contaminated by the food or wealth that has allowed them to live at another's expense.

As a verdict, a vengeful spirit accidentally killed while gardening concurrently identified a just culprit and distributed blame among all of Da Antony's dependents and descendants. Though the spirit had the right to exact revenge for its lost life, Da Antony could be regarded as an unwitting victim of his obligatory duty to support his family, thus allocating guilt more evenly among his wife, children, and grandchildren who lived off of the work that killed the python. What $\mathrm{Ba}$ Tyaiuwii had intimated was a conscious ethical lapse was rearticulated into a still dangerous, but more affirmative kind of collective affliction. If recognized, the spirit would become an agent of collective history, reminding all relevant kin of their common genealogical dependence on the unintended consequences of Da Antony's labor. Such an account coerced Da Antony's children and grandchildren to close ranks through the ritual services of Da Iwan - an older man from another lineage without $\mathrm{Ba}$ Tyaiuwii's competing claims to Da Antony's authority or status.

\section{DA IWAN'S TREATMENT}

Three days after the consultation with Da Iwan, I went to collect Da Antony and the members of his extended family to take them to the garden camp (kampu) of his wife, Ma Umankoni. There, an hour and a half outside of Paramaribo, Da 
Iwan would administer his treatment. The camp itself was nothing but two wood plank huts and a collection of outbuildings on the side of the then still war-scarred single lane road that snakes to the border with French Guiana. A sandy patch with scattered clumps of useful trees and shrubs, the carefully cleared yard quickly gave out in all directions to the stranglehold of thickly regrown jungle.

Upon arriving, Da Iwan set directly to work. Seated on a low stool, he began with a libation of clear rum. As he poured, Da Iwan recited a list of the invisible agents, starting with the creator deity (Masaa Gadu) and moving through his ancestors, his own possessing spirit, and the spirits of the place (goonmama) where he performed the ritual, which would help him rid Da Antony of his affliction. Such prayers indicate the role of genealogical time in Ndyuka conceptions of history. As a sequence leading back to ultimate origins in God, Ndyuka prayers narrate the hierarchy of ancestral powers responsible for producing the present from the distant past, and make this power felt by addressing the entire genealogy as senior co-participants in contemporary ritual action.

Upon completing the prayer, Da Iwan instructed one of Da Antony's granddaughters to bring him the stripped central stalk of a banana leaf. With a knife, he carved this into the rough zigzag of a slithering snake, cut a mouth, and inserted cowrie shell (papa moni) eyes to fashion an effigy of the afflicting python. He wrapped the effigy in a white cloth bound by a braided blue and white cord and placed it next to a large batik cloth flag tied to a stick stuck in the ground.

During these preparations, Da Antony's son-in-law, Ba Amansabi, arrived with the rest of the ritual supplies. On greeting him, Da Iwan commended him on having earlier concluded that Da Antony was not a victim of witchcraft. Witchcraft, Ba Amansabi thought, would have killed Da Antony much quicker than the chronic debility from which he currently suffered.

After assembling the ritual objects, Da Iwan set about preparing the medicine (obiya) to wash Da Antony and his extended family. In keeping with Ndyuka ideas about the body as a field of relations, ritual washing (wasi obiya) is a major means of obiya production and application. Obiya signifies both spirits and a generic class of medicinal therapy. Obiya can be a simple herbal preparation, or an elaborate cult of possession. In either case, obiya alters the composition of human agency to heal, extending the capacity for effective action by fusing people with the potent qualities of spirits and a pharmacopeia of semiotically dense ingredients (Price 2007; Thoden van Velzen and van Wetering 2004; Vernon 1992). Rituals "make" (meke) obiya by integrating materials like herbs, clay, alcohol, and tools with many overlapping laws (weiti), prohibitions (kina), spirit languages (winti tongo), songs (singi), dances (dansi), and prayers (begi) through performance. 
The multifaceted richness of obiya's semiotic form(s) is critical for appreciating how Ndyuka come to perceive afflictions as events through the human body. Da Iwan employed a number of different leaves that he either brought with him or found at the camp. These included papa uwii, said to be favored by python spirits, and konsaka uwii (come down leaf) and koo uwii (cool leaf), the names of which describe their intended effects: the removal of the afflicting spirit and the cooling of its anger.

The leaves were pulverized in a large wooden mortar and put in calabashes and sprinkled with powdered white clay (pemba). When all the ingredients had been combined and distributed, Da Iwan called Ba Amansabi behind my car. Seated on stools, Da Iwan took out a divination device made of a bulging wrapped object attached to a string. He instructed Ba Amansabi to ask the device any questions he had. Holding it still with one hand, elbow propped on his knee, Da Iwan watched as it swung faster to affirm Ba Amansabi's inquiry and he declared himself satisfied with the answer.

Da Iwan placed the python effigy on a white cloth on a banana leaf in the shade of a stand of small palm trees. Whispering instructions to the spirit, he speckled the effigy with the herbal mixture from a calabash, staining the cloth a desiccated brown, and set it aside. Together with Ma Umankoni, her children, and grandchildren, Da Iwan washed the seated Da Antony, dusting him with porcelain clay, and then showering him with a mixture of corn, taro, plantains, and un-husked rice. As they did so, they collectively implored ancestral help, declared they were feeding the avenging spirit, and begged it to forgive Da Antony and forsake his body. Finally, each circumambulating the stool in turn, all the family members washed Da Antony with the herbal formula.

Now the intensity of Da Iwan's speech mounted, and soon his spirit possessed him. He inscribed a circle with powdered clay and placed an egg at its center and, with the fluid swing of a machete, lopped the egg in two. All present exclaimed happily: the crisp dissection proclaimed that the spirit accepted the offerings and would save Da Antony.

We woke early the next morning to complete the treatment. As the quiet light of dawn hardened into tropical glare, Da Iwan drove a short wand and a decorated dagger into the ground to make a shrine for his spirit. The previous day's serpent effigy and some activating leaves were tied to a narrow plank. This was a carry oracle (tyai a ede) to house the python spirit so that it could communicate with the assembled family.

Da Iwan called everyone together and asked Ba Amansabi and his son to carry the oracle. He took some sangafu leaves, chewed them, and spat them on the crowns of both men's heads and then washed their feet with obiya water. Setting the plank on their heads, Da Iwan asked the spirit if it was present. Looking up at the motionless oracle with surprise and expectation, the two bearers stood still. Without waiting, Da Iwan took Ba Amansabi's son's 
place. Now the oracle moved immediately in fluid reply to Da Iwan's questions. Commenting on this, Da Iwan said that oracle bearers had different levels of ability defined by the sensitivity of their response to the "weight" (ebi) of the oracle's spirit. Some bearers responded fluently, others dumbly obstructed.

The man-spirit assemblage walked around the camp while Da Iwan kept up an almost inaudible conversation with the spirit. Taking her place in front of the family as they stood around the seated Da Antony, Ma Umankoni started the inquest by asking the oracle if it was responsible for her husband's affliction. The plank moved affirmatively forward. Da Antony's sister spoke next:

You must not take my brother! Why? Because you have tormented him enough already: he didn't know, we, the others here, didn't know, but it [the spirit] knew. The lanti (assembly) prays to it, his sister herself also prays to it, saying thank you, asking it to make [the illness] diminish, so that it [the spirit] removes its influence (lit. removes its hand) again. So I pray! Make it so that it doesn't kill him. Look at how the others have become weak at this point, how we are worried all the time.

Reciting a list of family members, Da Antony's sister inquired if the spirit was the cause of anyone else's sufferings. The spirit admitted that it was instigating Da Antony's wife, his sister, and third-eldest daughter's chronic neck pains. Sa Annette begged the spirit to specify who else in their family was immediately vulnerable to its vengeance. The spirit pointed to two of Da Antony's grandsons and his youngest daughter, all of whom are about the same age. The spirit then declared that everyone indicated must wash with its medicines.

The above ritual interaction carefully negotiates responsibility. Da Antony's sister portrays her brother and the rest of the family as ignorant of the python's killing. At the same time that she asserts their innocence of intent (if not action), she translates Da Antony's affliction into an event of collective suffering, connecting the spirit's revenge to misfortunes shared among the assembled family members. Assuming the stance of passive victims of $\mathrm{Da}$ Antony's accidental conduct sanctioned the family to equivocally confess their responsibility and represent their current pains as sufficient, or even excessive, punishments rightfully resolved through the present ritual. In this way, the family hoped to curtail the spirit's vengeance from becoming an intergenerational event of collective history.

At this juncture, the spirit signaled that it resided in a patch of sangafu plants very close to the place where the inquest was being held. There, Da Iwan said, they should bury the effigy and erect a shrine so the family could periodically come to pay it respect. The whole family angrily protested. The heretofore-silent Da Antony interjected, complaining loudly that the place was inappropriate for a shrine. With a scowl, Sa Annette objected that she would not come, and never had the time to travel all this way to pray to an avenging spirit. After conferring privately, the family told Da Iwan that they would only agree to bury the spirit in the bush across the road from the camp, and declared that that should end the matter. Though visibly discomfited, 
Da Iwan reluctantly acceded to the family's demand. He asked the spirit if what they suggested would suffice, and the oracle directly led them into a thick patch of undergrowth on the other side of the road. With this, everyone brightened and set off to the burial location with machete, pick, and shovel, and all of Da Iwan's medicines and paraphernalia.

Da Iwan indicated that they should bury the avenging spirit in a little patch of bare earth at the foot of a spindly tree less than 10 meters from the roadside. Da Iwan washed the spot with obiya solution and dug a shallow trench, filling it with leaves and twigs. Laying down the serpent effigy, he covered it with another layer of leaves, sprinkled it with clay, and buried it to the low murmur of his appeals. He drove the batik flag into the dirt at the head of the trench and poured out a libation.

Da Iwan grabbed a bound, speckled hen brought as an offering and placed it next to a small bench on which he sat Da Antony. Repeating the offerings of the day before, he sprinkled Da Antony with white clay and staple foodstuffs. This time, however, he submerged the struggling chicken in waiting buckets of obiya water and used its sodden plumage to wash the shivering Da Antony from head to foot. Ma Umankoni took a place next to Da Antony, and Da Iwan washed the two of them while loudly imploring the chicken to take their "sin" (zondu) and rid them of the spirit's anger. Da Iwan then impaled the chicken's neck on the flagpole, strongly declaring:

The whole family, everyone that has come washes with you. All of them come for the one who carried the whole country, the whole, whole family. You have done something that put all the people in one place; we are crying out, crying out for everyone, but those who come are everyone, are the (family?). We wash you, saying that you mustn't be angry, you mustn't fight: this would make you a bad (takuu) man. It is done, done, done, done, cleanly done. There mustn't be any more. It's finished, finished, finished, finished. Take it. Take it now. You must take it and not kill anyone.

This oration simultaneously addressed the spirit and family, narrating both in mutual opposition even as the fate of one was sutured to that of the other. When Da Antony is described in the third person as the "one who carried the whole country," he is recognized as the key ethical progenitor of the kin group that his sickness has made painfully evident in the bodies of all his relations. The spirit is acknowledged as this potent connection, the principle that forces the family's assembly into a particular unity in time and space. Concurrently, this rhetoric attempts to defeat the affliction's historical transmissibility. The spirit is emphatically told that its influence will not extend beyond the ritual. Believed or not, this discourse acts to assuage the family's corporate responsibility for Da Antony's transgression and constrain it to the ritual present.

With his bare hands, Da Iwan then exenterated the chicken and examined its entrails for signs that the offering had been accepted. Seeing a whitish lump, Da Iwan declared the ritual a success. The disemboweled fowl was laid on a bed of leaves next to a nearby fallen tree and left with an egg and a scattering 
of white clay. The rest of the family took their turns washing, first those stipulated to do so by the oracle, then everyone else, including myself. As we washed, we called out: "I am washing, I am washiiiing, my elders (gaansama)!" and requested wealth, luck, and other benedictions. The ritual baths complete, Da Iwan heaped the excess leaves over the effigy's burial place, implanting the exhausted heap with another egg and a small bottle of liqueur (switi sopi). The ritual was concluded when libations of beer, rum, and soda were poured over the python spirit's burial mound and shared out in tiny sips between all of us.

Da Iwan's treatment shows Da Antony's family grappling with an event of affliction to simultaneously ascertain and limit collective responsibility. Da Iwan's divinations made the spirit's agency and the family's guilt manifest in joint suffering like eerily similar neck pains. This apparent fait accompli, however, empowered the family to wrest back control over explanations of responsibility. The resulting ritual exorcism presents a counterpoint of revelation and confutation in which the gathered family accepts the results of divination even while they resist the transformation of the serpent spirit into a hereditary, historical force able to stipulate the terms of the family's shared future existence. Rather than accept the spirit's metastasis to descendent generations that would make it a permanent agent of lineage history, the assembled family members used their collective influence as ritual patrons to restrain the event of Da Antony's affliction. Successfully opposing the spirit's request to build a shrine, the family insisted on the finiteness of the event, circumscribing the "action-radius" (Thoden van Velzen 1966: 49) of the affliction to only the gathered family members. Such arbitrations permit Ndyuka some control over seemingly unappeasable hereditary destiny. Rather than erect inflexible temporal laws, ritual revelations of responsibility invite the living to bargain with the past over the shape of the future. With the spirit's concession to a poorly marked grave, the family guaranteed that the extremes of tropical weather would soon obliterate it from collective memory.

Sadly, Da Antony did not recover. His radiation therapy dragged on and he grew weaker. Exhausted, he succumbed to melancholic regret (kusumi). Within a month he stopped eating even the thin gruel on which he lived and faded to a hollow presence adrift in a low-slung hammock in the corner of the room. Within two months of Da Iwan's purported exorcism of the avenging spirit, Da Antony died. On the day of his death, I was at home with a mild fever. When one of his daughters called with the news, she construed my own sickness as a "mark" (maiki) of my relational entanglement with Da Antony in the last year of his life.

Because he was a member of one of the up-river clans who maintain Da Akalali's prohibition on corpse divination, Da Antony was buried without a determination of final culpability. His family performed public resignation to what they had come to accept as Da Antony's inevitable death, but they remained angry and blamed his doctors and jealous family members. Outraged 
by the failure of the exorcism, some of Da Antony's grandchildren charged Da Iwan with, out of either malice or incompetence, causing their grandfather's death. ${ }^{11}$ At last report (October 2016), Da Antony's family had chiefly settled on Da Antony's own preferred explanation of witchcraft, exculpating themselves from wrongdoing and forestalling any extension of the affliction into a contagious event of corporate history. Only if Da Antony's ghost possessed a medium within the family to mandate justice would they take action. History would be made only if forced on the family through the magnified power of Da Antony's voice manifested in future misfortune. Until then the family preferred to wait.

In Da Iwan's healing, Da Antony's family took the chance to assert its will to curtail the ways their collective guilt could be felt as history - a defining narrative of the past's relation to the present. Their attempts to ritually control the intergenerational consequences of his affliction bring us to an old problem in Surinamese Maroon ethnography. As Richard Price (1973) showed for the closely related Saamaka Maroons, despite lineage members' professions to the "eternality" of matrilineages and their avenging spirits, over time Saamaka lineages frequently segmented as their avenging spirits lost retributive power. As Price puts it, "The consequences of kunu findings ... for the structure of particular bées are widely divergent. In some cases they reinforce and formalize emerging fissures within the bée; in others they create new divisions; sometimes they serve to ostracize an individual; and they may even have the effect (by reminding an increasingly independent bée section of its vulnerability to the bée's common kunus) of pulling together a loosely structured bée" (1973: 105).

Based on my own research, the divergences Price notes in different Saamaka lineages' responses to avenging spirits are, at least in part, the result of common Maroon struggles to derive responsibility for sickness and death from the qualities of events of affliction. Taken together, Price's observation and $\mathrm{Da}$ Antony's therapeutic quest disclose the incessant efforts of Ndyuka and other Maroons to come to grips with the consequences of past transgressions on the conditions of present. Since the importance of Maroon descent is largely imparted by the ways in which it is revealed as a present existential threat, Maroon kin groups must continually update their collective histories to accord with the previously unknown relations revealed in current misfortunes. In this way, whether suffered by one person or many, the qualities of any moment of misfortune can compel Maroon kin groups to redefine who they are by re-describing the historical relations they will be responsible for in the

\footnotetext{
11 Tragically, three years after her father's death, Da Antony's daughter Sa Annette suffered a stroke. As my field assistant John later explained to me, he surmised that her cousin Thomas had indeed been correct when he diagnosed the cause of the sickness as fiofio, because not only had Da Antony lost his voice - a clear sign of retaliation for socially corrosive verbal conflictbut his daughter was subsequently afflicted with the same malady. In this way he was fairly sure that this was a disease that "coursed through the lineage" (waka ini a bée).
} 
future. Though the oldest memories of ethnic, clan, and lineage history appear less subject to modification, more recent historical relations that determine the everyday social conduct of most Maroons are likely the result of such cumulative histories of ritual revision.

That patrilineality is granted precedent in all of Da Antony's contending diagnoses is an important example of ritually mediated changes to conceptions of historical responsibility. Maroon resettlement on the coast has forced Maroons to adapt to legal and economic practices that naturalize the norm of the male-centered nuclear family. Despite the many ways in which the social realities of Maroon life trouble this paradigm, as the commonsense of the postcolonial state, it remains unquestioned, if not untested. Da Antony's therapies show one way in which Ndyuka ritual has responded to this challenge. Slowly but steadily, formerly matrilineally defined "differential kunu vulnerability" shifts to patrilineal relations (Green 1977: 150). The textures of temporality that tie before to after thus subtly change as new pasts reveal their immediacy to an emergent future. As this happens, the symptoms of affliction events come to indicate patrilineal origins for synchronous misfortunes among patrilateral kin. As Da Antony's case illustrates, different Ndyuka diagnoses of events of affliction spin divergent historical reckonings, parsing kinship to create new consensuses about personal and collective accountability. In rituals to affix responsibility, Maroon relations are thus reinvented to answer the evidences of the present, subtly shifting history to articulate the demands of new social realities (Köbben 1967; 1969a; 1969b).

\section{CONCLUSION}

This article has attempted to describe the intersection of events of affliction and revelation in the making of contemporary Ndyuka history. I have presented three competing descriptions of Da Antony and his family's responsibility for his affliction: as passive victims of witchcraft, accidental killers of an avenging spirit, and imprudent provocateurs of the moral preconditions of kinship. Once widely accepted among a kin group, such descriptions extend or deny new possibilities for history and correspond to efforts to make sense of personal, collective, and environmental responsibility within an irreducibly social world where the present and past are unavoidably interdependent. Such compressed, often opaque, mutuality leads Ndyuka to hazard accurate assessments of responsibility even as they try and constrain the socially combustible and even tragic outcomes of these inquiries. History results when the pooled signs of responsibility become excruciating and members of a social group feel they have no choice but to see their pains as addressed from the past to a fused future destiny. Because the cost of such historical recognition is so high, many Ndyuka fight to restrain events of affliction to the present and forestall conflicts between kin that result from the need to enforce communal acknowledgements of guilt. 
For many Ndyuka, seeming historical anachronisms like a long-dead serpent alive in disease thus found the ethical coherence of personal subjectivity and social categories like the lineage. As with many contemporary political confrontations over the metaphysics of responsibility, for the family members who gathered to relieve Da Antony of his pain, the qualities of their suffering rendered history up for grabs. Rather than attenuated traces buried beneath the onrush of unforgiving time, by demanding accountability for the past through the qualities of present pain Da Antony's suffering revealed that history is both a living, even ominous presence with unsurpassed power to determine his family's future, and an evidential problem always potentially open to revision.

Trouillot (1995) convincingly distinguished the material traces of the past (history 1) from the narratives people use such evidence to create (history 2). Ndyuka struggles with their own ideologies of historicity show how consequential different regimes of interpreting material evidence can be for defining the kinds of history people narrate. The "scandal" (Chakrabarty 2000) of translating between discordant historicities therefore illuminates the "aporia" implicit in any particular concept of history (Palmié 2014). As Trouillot established, the silences and omissions of standard historical narratives divulge forms of epistemic power implicit in any method of history production. Just as seizing control of etiologies of affliction sanctions Ndyuka mediums to redefine the past in sometimes violently revolutionary ways, even the best academic historiography enforces the hegemony of a "particular rather than universal type of agentive subject" "rendered intelligible" by an evidential regime "in which responsibility for present states of affairs can be assigned to the past actions of such subjects on the basis of proper evidence that they freely chose such courses of action" (ibid.: 231); a metaphysic of choice is, after all, no more inevitably obvious within the material remains of the past than is the python's wrath in Da Antony's smothered voice.

Indeed, in the same way the possibility that an Ndyuka person or lineage might not bear responsibility for a given misfortune underwrites accepting the necessity of a palpably grievous experience of historical accountability, so too the autonomous individuals freed to choose their fate by the contingency of academic history yield conflicted narratives about the present moral implications of the past's traces. Concomitantly an inexorable current consigning the past to inconsequence, and a rigid causal principal, the contingency of individual choice that sequences secular historical time saturates without resolving pivotal contemporary disputes over responsibility, from reparations for slavery to climate change. In this regard, as a precondition for empirical research, and an all too politically expedient means of complicating the present's liability to the past, the contingency to choose that endows the subjects and temporal structure of academic history with cogency creates a situation similar to Da Antony's attempts to assuage responsibility. In describing what did happen, historians must limit what could happen to "individuals" their "wills," "agency," and 
"responsibility"__all highly functional fictions that underwrite a specific and historical, rather than universal and timeless order" (ibid.: 231).

If, as Johnson (2014) persuasively argues, the very model of the autonomous agent enthroned in academic historicism is a byproduct of European attempts to justify the slavery and colonial expansion that brought the Ndyuka ancestors to Suriname against their will, then the juxtaposition of these different metaphysics of accountability disclose the ethical conundrums unavoidably posed by any paradigm of history. What might it say that a model of historical agency derived from rationalizations for enslavement can also be used to rebuff attempts to demand present-day moral accountability for that selfsame history? For though the tragic consequences of Ndyuka history compel many Ndyuka to battle to redefine their historical responsibility, they nevertheless resolutely accept its inescapable necessity.

\section{REFERENCES}

Akin, David. 2003. Concealment, Confession, and Innovation in Kwaio Women's Taboos. American Ethnologist 30, 3: 381-400.

Anscombe, G.E.M. 1957. Intention. Oxford: Blackwell.

Bakhtin, M. M. 1981. The Dialogic Imagination: Four Essays. Austin: University of Texas Press.

Benjamin, Walter. 1967. Illuminations. New York: Random House.

Bilby, Kenneth. 1990. The Remaking of the Aluku: Culture, Politics, and Maroon Ethnicity in French South. PhD diss., Johns Hopkins University.

Bubandt, Nils. 2014. The Empty Seashell: Witchcraft and Doubt on an Indonesian Island. Ithaca: Cornell University Press.

Cashell, Kieran. 2013. Ex Post Facto: Peirce and the Living Signs of the Dead. Transactions of Charles S. Peirce Society 43(2): 345-71.

Chakrabarty, Dipesh. 2000. Provincializing Europe: Postcolonial Thought and Historical Difference. Princeton: Princeton University Press.

Chakrabarty, Dipesh. 2009. The Climate of History: Four Theses. Critical Inquiry 35: 197-222.

Collingwood, R. G. 1946. The Idea of History. Oxford: Clarendon Press.

Douglas, Mary. 1980. Edward Evans-Pritchard. New York: Viking Press.

Douglas, Mary. 2004 [1970]. Witchcraft Confessions and Accusations. London: Routledge.

Evans-Pritchard, E. E. 1937. Witchcraft and Oracles among the Azande. Oxford: Oxford University Press.

Fasolt, Constantin. 2004. The Limits of History. Chicago: University of Chicago Press.

Fasolt, Constantin. 2005. The Limits of History in Brief. Historically Speaking 6: 5-10.

Favret Saada, Jeanne. 1981. Deadly Words: Witchcraft in the Bocage. Cambridge: Cambridge University Press.

Favret Saada, Jeanne. 2015. The Anti-Witch. Chicago: University of Chicago Press.

Geschiere, Peter. 2013. Witchcraft, Intimacy, and Trust: Africa in Comparison. Chicago: University of Chicago Press.

Gluckman, Max. 1972. The Allocation of Responsibility. Manchester: Manchester University Press.

Green, Edward. 1977. Matawai Lineage Fission. Bijdragen tot de Taal-, Land- en Volkenkunde 133, 1: 136-54. 
Hacking, Ian. 1995. Rewriting the Soul: Multiple Personality and the Sciences of Memory. Princeton: Princeton University Press.

Holbraad, Martin. 2012. Truth in Motion: The Recursive Anthropology of Cuban Divination. Chicago: University of Chicago Press.

Horton, Robin. 1997. Patterns of Thought in Africa and the West: Essays on Magic, Religion and Science. Cambridge: Cambridge University Press.

Johnson, Paul Christopher. 2014. Towards an Atlantic Genealogy of 'Spirit Possession.' In Paul Christopher Johnson, ed., Spirited Things: The Work of Possession in Afro-Atlantic Religions. Chicago: University of Chicago Press, 23-46.

Kapferer, Bruce. 2015. Introduction. In Lotte Meinert, ed., The Event: Toward an Anthropology of Generic Moments. New York: Berghahn Books, 1-28.

Keane, Webb. 2003. Semiotics and the Social Analysis of Material Things. Language and Communication 23, 2-3: 409-25.

Keane, Webb. 2007. The Christian Moderns: Freedom and Fetish in the Mission Encounter. Berkeley: University of California Press.

Keane, Webb. 2015. Ethical Life: Its Natural and Social Histories. Princeton: Princeton University Press.

Köbben, André. 1967. Unity and Disunity: Cottica Djuka Society as a Kinship System. Bij dragen tot de Taal-, Land-en Volkenkunde 123: 10-52.

Köbben, André. 1969a. Classificatory Kinship and Classificatory Status: The Cottica Djuka of Surinam. Man 4: 236-49.

Köbben, André. 1969b. Law at the Village Level: The Cottica Djuka of Surinam. In L. Nader, ed., Law in Culture and Society. Berkeley: University of California Press, 117-40.

Laidlaw, James. 2014. The Subject of Virtue: An Anthropology of Ethics and Freedom. Cambridge: Cambridge University Press.

Lambek, Michael. 1998. The Sakalava Poiesis of History: Realizing the Past through Spirit Possession in Madagascar. American Ethnologist 25: 106-27.

Lambek, Michael. 2003. Rheumatic Irony: Questions of Agency and Self-Deception as Refracted through the Art of Living with Spirits. Social Analysis 47: 40-59.

Latour, Bruno. 1992. We Have Never Been Modern. Cambridge: Harvard University Press.

Lempert, Michael 2011. Avoiding "The Issues" as Addressivity in US Electoral Politics. Anthropological Quarterly 84, 1: 187-207.

Löwith, Karl. 1949. Meaning in History: The Theological Implications of the Philosophy of History. Chicago: University of Chicago Press.

MacGovern, Mike. 2012. Turning the Clock Back or Breaking with the Past: Charismatic Temporality and Elite Politics in Côte d'Ivoire and the United States. Cultural Anthropology 27, 2: 239-60.

Moomou, Jean. 2013. Les Marrons boni de Guyane: luttes et survie en logique coloniale (1712-1880). Guyane: Editions Ibis Rouge.

Moomou, Jean. 2016. "Représentations et pratiques sociales autour du temps chez les descendants des Marrons du Surinam de la vallée du Maroni en Guyane française." Amerika 14. URL: http://journals.openedition.org/amerika/7315; DOI: 10.4000/ amerika.7315 (published 22 June, consulted 26 Dec. 2017).

Munn, Nancy. 1986. The Fame of Gawa: A Symbolic Study of Value Transformation in a Massim Society. Cambridge: Cambridge University Press.

Overing, Joanna. 1990. The Shaman as a Maker of Worlds: Nelson Goodman in the Amazon. Man 25, 4: 602-19.

Palmié, Stephan. 2014. Historicist Knowledge and Its Conditions of Impossibility. In D. Espirito Santo and R. L. Blanes, eds., The Social Life of Spirits. Chicago: University of Chicago Press, 218-39, 258-63. 
Palmié, Stephan and Charles Stewart. 2016. Introduction: For an Anthropology of History. Hau 6, 1: 207-36.

Parmentier, Richard J. 1985. Times of the Signs. In Elizabeth Mertz and Richard J. Parmentier, eds., Semiotic Mediation: Sociocultural and Psychological Perspectives. Orlando: Academic Press, 131-54.

Parris, J.-Y. 2011. Interroger les morts: essai sur le dynamisme politique des noirs Marrons Ndjuka du Surinam et de la Guyane. Matoury: Ibis Rouge.

Price, Richard. 1973. Avenging Spirits and the Structure of Saramaka Lineages. Bijdragen tot de Taal-, Land-, en Volkekunde 129: 86-107.

Price, Richard. 1983. First Time: The Historical Vision of an Afro-American People. Baltimore: Johns Hopkins University Press.

Price, Richard. 2007. Travels with Tooy: History, Memory, and the African American Imagination. Chicago: University of Chicago Press.

Robbins, Joel. 2008. On not Knowing other Minds: Confession, Intention, and Linguistic Exchange in a Papua New Guinea Community. Anthropological Quarterly 81, 2: 421-29.

Sahlins, Marshall. 1981. Historical Metaphors and Mythical Realities: Structure in the Early History of the Sandwich Islands Kingdom. Ann Arbor: University of Michigan Press.

Sahlins, Marshall. 1985. Islands of History. Chicago: University of Chicago Press.

Schieffelin, Edward. 1985. The Retaliation of the Animals: On the Cultural Construction of the Past in Papua New Guinea. In Deborah Gewertz and Edward Schieffelin, eds., History and Ethnography in Papua New Guinea. Sydney: University of Sydney Press, 40-57.

Strange, S. E. 2016. The Dialogical Collective: Mediumship, Pain, and the Interactive Creation of Ndyuka Maroon Subjectivity. Journal of the Royal Anthropological Institute 22: 516-33.

Thoden van Velzen, H.U.E. 1966. Het geloof in wraakgeesten: Bindmiddel en splijtzwam van de Djuka matri-lineage. Nieuwe West-Indische Gids 45: 45-51.

Thoden van Velzen, H.U.E. and W. van Wetering. 2004. In the Shadow of the Oracle: Religion as Politics in a Suriname Maroon Society. Long Grove: Waveland Press.

Thoden van Velzen, H.U.E. and W. van Wetering. 2007. Violent Witch Finders and the Suspension of Social Order in a Suriname Maroon Society. In Rob van Ginkel and Alex Strating, eds., Wildness \& Sensation: Anthropology of Sinister and Sensuous Realms. Apeldoorn: Het Spinhuis, 157-76.

Thoden van Velzen, H.U.E. and W. Hoogbergen. 2011. Een Zwarte Vrijstaat in Suriname: de Okaanse samenleving in de $18 E$ Eeeuw. Leiden: KITLV.

Trnka, Susanna and Catherine Trundle. 2014. Competing Responsibilities: Moving beyond Neoliberal Responsibilisation. Anthropological Forum 24, 2: 1-18.

Trouillot, Michel-Rolph. 1995. Silencing the Past: Power and the Production of History. Boston: Beacon Press.

Turner, Victor. 1968. The Drums of Affliction: A Study of Religious Processes among the Ndembu of Zambia. Oxford: Clarendon.

Vernon, Diane. 1980. Bakuu: Possessing Spirits of Witchcraft on the Tapanahony. Nieuwe West-Indische Gids 54, 1: 1-38.

Vernon, Diane. 1992. Les représentations du corp chez les noirs Marrons Ndjuka du Suriname et la Guyane Française. Paris: Editions de I'ORSTOM.

West, Harry. 2007. Ethnographic Sorcery. Chicago: University of Chicago Press.

Wirtz, Kristina. 2016. The Living, the Dead, and the Immanent: Dialogue across Chronotopes. Hau 6, 1: 343-69. 
Abstract: Questions of responsibility are central to the politics and metaphysics of history. This paper examines the creation of different histories from alternative formulations of personal and collective responsibility among urban Ndyuka Maroons in present-day Suriname. Tracing conflicting attempts to assign accountability for a senior man's sickness, I argue that a distinctly Ndyuka conception of history emerges from the dialectical relation between the material qualities of misfortunes and the practices Ndyuka use to affix responsibility. Ndyuka efforts to assuage history as embodied by ghosts and other spirits that seek revenge on corporate kin groups simultaneously use the symptoms of misfortune to make history and attempt to contain or deny the transmissibility of collective responsibility to future generations. Understanding this process demonstrates how distinct perceptions of historicity emerge from different conceptions of responsibility, and the extent to which intergenerational sociality is defined by conflicted attempts to redefine historical accountability as much as to acknowledge it.

Key words: responsibility, history, misfortune, kinship, Ndyuka Maroons, Suriname 